\title{
Associations of colors with Russian vowels
}

\author{
YURI A. TAMBOVTSEV \\ Novosibirsk University, Novosibirsk, U.S.S.R.
}

(Lawrence E. Marks, Sponsor)

\begin{abstract}
One hundred and twenty-six native speakers of Russian selected from 19 color names the colors (hues and lightnesses) that they imagined to correspond to each of 10 written Russian vowels and letters. Most vowels and letters were judged light in color, although 3 [æ] and Ы [I] were judged dark. Overall, the present results differ markedly from those reported for native speakers of French, German, and English, and call for further evaluation of color-sound associations across unrelated languages.
\end{abstract}

The study of sound symbolism-the meanings implied by sounds, especially speech sounds-includes the study of color-sound symbolism-the hues, saturations, and brightnesses implied by sounds. Sound symbolism in general and color-sound symbolism in particular involve synesthetic connections across different sensory modalities (see Marks, 1975). The linguist Roman Jakobson considered colors to characterize only vowels, not consonants (Jakobson \& Waugh, 1979), although many people also can easily imagine colors of consonants, especially sonorants. The search for color associates of sounds has influenced many studies of vowels (Delattre, Liberman, Cooper, \& Gerstman, 1952; Tambovtsev, 1980, 1981; Zhuravljov, 1974) and a few studies of consonants (e.g., Molnar, 1984; Filippova, 1980).

In my view, the question of color-sound associations should be evaluated in as many languages as possible in order to discern whether any of the associations are universal, whether the associations are strictly characteristic of individuals, or whether the associations are limited to certain languages. One may compare sound symbolism in genetically related languages, for instance, Russian (Zhuravljov, 1974) and Ukranian (Levickij, 1973), and then compare their common features with features of other languages, such as Navajo, with different genetic origins and phonetic-morphological structures (see Atzet \& Gerard, 1965).

I became involved in studies of color-sound association in 1976, after a discussion of the features of sound symbolism in the Laboratory of Experimental Phonetics at Leningrad University. The point of departure was the study by Zhuravljov (1974). Zhuravljov provided 125 native Russian informants with a list of six vowels and six colors; the informants' task was to assign to every vowel

I thank my students at Novosibirsk University who answered the questionnaire. I am also grateful to Irene Seliber, who helped test students of the Pediatric-Medical Institute in Leningrad. I acknowledge useful remarks by L. V. Bondarko and A. P. Zhuravljov. Finally, I thank L. E. Marks for helpful comments and for editing the manuscript. Address correspondence to Yuri Tambovtsev, Lvov Institute of Forestry, Pushkina 103, 290032 Lvov, U.S.S.R. just one color, and to assign different colors to all vowels. Those results showed clear evidence for specific color-vowel relations, with the vowel [o] called white or yellow, [I] black, and [a] red. In the present study I sought to verify Zhuravljov's results, using a procedure that did not require subjects to assign a different color to each sound.

\section{METHOD}

The aim was to determine correlations between colors and Russian vowels perceived by native speakers of Russian. The subjects were asked to imagine the colors of 10 Russian phonemes and letters (see Table 1) presented in written form, and to indicate the color of each: red, orange, yellow, brown, green, blue, violet, black, gray, or white. For all colors but white, the subjects could indicate whether the shade was dark or light. In addition, the subjects could indicate their refusal or failure to assign a color to any given vowel. The subjects were 68 men and 58 women, all university students, ranging in age from 17 to 25 years.

\section{RESULTS AND DISCUSSION}

The results are summarized in Table 2 . For convenience, I have collapsed here responses across light and dark shades of each color; the last column of the table indicates the number of both light and dark color responses given to each vowel. It is clear that each letter (vowel sound) produced a relatively distinct pattern of responses;

Table 1

Russian Vowels Used in the Experiment

\begin{tabular}{clc}
\hline Vowel & \multicolumn{1}{c}{$\begin{array}{c}\text { English } \\
\text { Pronunciation }\end{array}$} & $\begin{array}{c}\text { Phonetic } \\
\text { Representation }\end{array}$ \\
\hline $\mathbf{A}$ & a as in hot & {$[\mathrm{a}]$} \\
$\mathbf{O}$ & o as in home & {$[\mathrm{o}]$} \\
y & oo as in soon & {$[\mathrm{u}]$} \\
3 & between a as in hat & {$[\mathrm{a}]$} \\
& and e as in bet & {$[\varepsilon]$} \\
$\mathbf{b}$ & i as in pit & {$[\mathrm{I}]$} \\
$\mathbf{H}$ & ee as in me & {$[\mathrm{i}]$} \\
$\mathbf{G}$ & ya as in yacht & {$[\mathrm{ja}]$} \\
Ю & yoo as in you & {$[\mathrm{ju}]$} \\
$\ddot{\mathrm{E}}$ & yo as in yoke & {$[\mathrm{jo}]$} \\
$\ddot{\mathbf{H}}$ & y as in yes & {$[\mathrm{j}]$} \\
\hline
\end{tabular}


Table 2

Sound-Color Correlations in Russian, Judged by Native Russians $(N=126)$

\begin{tabular}{|c|c|c|c|c|c|c|c|c|c|c|c|c|c|c|c|c|c|c|c|c|c|}
\hline \multirow[b]{2}{*}{ Vowel } & \multicolumn{2}{|c|}{ Red } & \multicolumn{2}{|c|}{ Orange } & \multicolumn{2}{|c|}{ Yellow } & \multicolumn{2}{|c|}{ Brown } & \multicolumn{2}{|c|}{ Green } & \multicolumn{2}{|c|}{ Blue } & \multicolumn{2}{|c|}{ Violet } & \multicolumn{2}{|c|}{ Black } & \multicolumn{2}{|c|}{ Gray } & \multicolumn{3}{|c|}{ No } \\
\hline & L & $\mathrm{D}$ & $\mathrm{L}$ & D & $\mathrm{L}$ & D & $\mathrm{L}$ & D & $\mathrm{L}$ & D & $\mathrm{L}$ & D & $\mathrm{L}$ & D & $\mathrm{L}$ & D & $\mathrm{L}$ & D & White & Correlation & Total \\
\hline A & 45 & 11 & 4 & 4 & 9 & - & - & 7 & 2 & 4 & 11 & 5 & - & 3 & - & 5 & 4 & - & 12 & 0 & 126 \\
\hline $\mathrm{O}$ & 4 & 4 & 9 & 5 & 12 & 2 & 9 & 17 & 5 & 8 & 15 & 9 & 2 & - & 2 & 10 & 5 & - & 4 & 4 & 126 \\
\hline $\mathbf{y}$ & 4 & 2 & 9 & 5 & 15 & 6 & 11 & 9 & 9 & 1 & 4 & 7 & 14 & 11 & 7 & 6 & 2 & 2 & 2 & 0 & 126 \\
\hline 3 & 4 & 3 & 10 & 6 & 7 & 3 & 4 & 20 & 10 & 7 & 4 & 5 & 6 & 7 & 2 & 4 & 9 & 7 & 6 & 2 & 126 \\
\hline Ы & 6 & 2 & 2 & 5 & 3 & 8 & 8 & 8 & 6 & 3 & 6 & 4 & 6 & 14 & 11 & 14 & 10 & 7 & 3 & 0 & 126 \\
\hline и & 8 & 2 & 11 & 8 & 11 & 5 & 4 & 2 & 5 & 7 & 20 & 5 & 9 & 1 & 7 & 3 & 8 & 3 & 7 & 0 & 126 \\
\hline Я & 16 & 6 & 13 & 3 & 10 & 11 & 2 & 1 & 7 & 6 & 10 & 8 & 6 & 3 & 5 & 3 & 2 & 2 & 12 & 0 & 126 \\
\hline Ю & 2 & 2 & 9 & 4 & 7 & 6 & 8 & 10 & 12 & 3 & 10 & 4 & 16 & 4 & 2 & 11 & 10 & 4 & 2 & 0 & 126 \\
\hline$\ddot{\mathrm{E}}$ & 5 & 2 & 9 & 3 & 4 & 2 & 7 & 8 & 15 & 14 & 10 & 7 & 4 & 7 & 4 & 1 & 4 & 13 & 6 & 1 & 126 \\
\hline Й & 15 & 5 & 5 & 2 & 3 & 11 & 6 & 1 & 10 & 6 & 6 & 6 & 6 & 4 & 8 & 6 & 4 & 4 & 17 & 1 & 126 \\
\hline Total & 109 & 39 & 81 & 45 & 81 & 54 & 59 & 83 & 81 & 59 & 96 & 60 & 69 & 54 & 48 & 63 & 58 & 42 & 71 & 8 & 1,260 \\
\hline
\end{tabular}

Note $-\mathrm{L}=$ light, $\mathrm{D}=$ dark.

that is, each had an identifiable cluster of color associates. A [a], for instance, was typically red, whereas $\mathrm{O}$ [o] was brown or blue, and $\mathbf{Y}[\mathrm{u}]$ was violet, brown, or yellow.

First, it is instructive to compare these results with those of Zhuravljov (1974). Emerging from the comparison are both points of agreement and points of disagreement. The present study and Zhuravljov's agree in showing A [a] to be red, $\mathbf{H}[\mathbf{~ I ]}$ to be predominantly black, and $И$ [i] to be blue. On the other hand, $O[0]$ was blue and brown in the present study, but white in Zhuravljov's; $\mathrm{Y}$ [u] was violet, yellow, and brown here in the present study, green and blue in Zhuravljov's; 3 [æ] was brown, green, orange, and gray in the present study, green and yellow in Zhuravljov's. In sum, there are both agreements and disagreements, some of which may reflect differences in procedure: recall that in Zhuravljov's study, it was not possible for an informant to assign the same color to two sounds.

Second, it is instructive to look at the patterns of light and dark color responses revealed in Table 2 . Clearly, most of the vowels received a preponderance of light color responses. The only exceptions are 3 [æ] and b [I], both of which were judged dark more often than light. Native speakers of French, German, and English, however, give a rather different pattern of light/dark color responses, judging [I] and [i] to be light, [o] and [u] to be dark (see Marks, 1975). In general, Marks's summary showed a direct correspondence between vowel pitch and color brightness.

Despite the evidence of the present findings that certain colors are associated with particular vowels in the imagination of Russian speakers, it is not clear that the color-sound associations in Russian agree totally with those reported in other languages (see Marks's, 1975, review). To be sure, some notes of agreement appear: The vowel [a], for instance, is generally called red. But notable disagreements also exist. For example, highpitched vowels such as [i] and [I], which Marks found were most often called white, light, or yellow in hue, were reported in the present study largely as blue, violet, or black. Marks showed that the relation of visual lightness or brightness to pitch of sounds is very strong, transcending mere color-sound symbolism and being a general characteristic of cross-modal and synesthetic perception. Perhaps, then, the discrepancy between the present results and those reviewed by Marks derives at least in part from the presentation of the vowels in visual format in the present study. In any case, the difference calls for further evaluation of color-sound associations across unrelated languages.

\section{REFERENCES}

Atzet, J., \& Gerard, H. B. (1965). A study of phonetic symbolism among native Navajo speakers. Journal of Personality \& Social Psychology, 1, 524-528.

Delattre, P. C., Liberman, A. M., Cooper, F. S., \& Gerstman, L. J. (1952). An experimental study of the acoustic determinants of vowel color. Word, 8, 195-210.

FilıPPOVA, T. S. (1980). Znacimostj zvukov russkoj reci v vosprijatii nositelej poljskogo jazka [The meaning of Russian speech sounds in the perception of Polish speakers]. In A. P. Zhuravljov (Ed.), Vosprijatie jazykovogo znacenija (pp. 149-157). Kaliningrad: Kaliningrad University.

JAKOBSON, R., \& WAUGH, L. (1979). The sound shape of language. Bloomington: Indiana University Press.

LEVICKIJ, V. V. (1973). Simvoliceskie znacenija ukrainiskih glasnyh i soglasnyh [Symbolic meaning of Ukranian vowels and consonants]. Movoznavstvo, 2, 36-49.

MarKs, L. E. (1975). On colored-hearing synesthesia: Cross-modal translations of sensory dimensions. Psychological Bulletin, 82, 303-331.

MolNAR, T. I. (1984). A magyar beszedhangok szubjektiv elemi szimbolikaja [Subjective elementary symbolism of Hungarian speech sounds]. Debecen: Debecen University.

TAMBOVTSEV, YU. A. (1980). Nekotorye cretovye sootvetstvija anglijskih glasnyh fonem u muzcin-nositelej russkogo jazyka [Some color correlations of English vowel phonemes of Russian-speaking males]. In A. P. Zhuravljov (Ed.), Vosprijatie jasykovogo znacenija (pp. 157161). Kaliningrad: Kaliningrad University.

TAMBOvTSEv, YU. A. (1981). Cvetovye sootvetstvija anglijskih glasnyh fonem u nositelej russkogo jazyka [Color correlations of English vowel phonemes of Russian speakers]. In V. N. Kuprejanova (Ed.), Leksiko-grammaticeskie issledovanija (pp. 74-79). Novosibirsk: Nauka.

Zhuravluov, A. P. (1974). Foneticeskoe znacenie [Phonetical meaning]. Leningrad: Leningrad University.

(Manuscript received for publication November 16, 1987.) 